\title{
PELATIHAN PENGGUNAAN SOFTWARE PENILAIAN KESEHATAN HUTAN DI KTH LESTARI INDAH LABUHAN MARINGGAI LAMPUNG TIMUR
}

\author{
Rahmat Safe'i', Aristoteles ${ }^{2}$, Unang Mulkhan ${ }^{3}$, M. Rizky Pratama ${ }^{4}$, Lis Nur Ajijah ${ }^{5}$, \\ A. Nizam Syahiib ${ }^{6}$, Selvira $^{7}$, Annisa Putri Nabila ${ }^{8}$, Risna Damayanti9 \\ (1) Program Studi Magister Kehutanan, FP, Universitas Lampung, Lampung, 35144, Indonesia \\ (2) Jurusan Ilmu Komputer, FMIPA, Universitas Lampung, Lampung, 35142, Indonesia \\ (3) Jurusan Administrasi Bisnis, FISIP, Universitas Lampung \\ 4,5,6,7,8,9 Mahasiswa Jurusan Kehutanan, FP, Universitas Lampung \\ Penulis Korespodensi: rahmat.safei@fp.unila.ac.id
}

\begin{abstract}
Abstrak
Pentingnya pengetahuan perihal kesehatan hutan yaitu diperlukan untuk mengetahui gangguan yang terjadi, sehingga perlu dilakukan pemantauan kesehatan hutan secara berkala. Pemantauan kesehatan hutan adalah salah satu cara untuk menjamin kelestarian hutan salah satunya hutan mangrove. Pengabdian ini bertujuan untuk meningkatkan pemahaman anggota Kelompok Tani Hutan (KTH) Lestari Indah mengenai penggunaan Sistem Informasi Penilaian Kesehatan Hutan (SIPUT). Sasaran pengabdian ini adalah anggota KTH Lestari Indah. Tingkat pemahaman peserta perlu diketahui sehingga dilakukannya evaluasi melalui dua tahap yaitu evaluasi awal (pre-test) dan evaluasi akhir (post-test) dengan cara pemberian kuesioner. Hasil perhitungan menunjukkan bahwa terjadi peningkatan pemahaman peserta tentang penggunaan software penilaian kesehatan hutan yaitu dengan rerata nilai pre-test dan post-test masing-masing sebesar $61,125 \%$ dan $80,125 \%$. Persentase kenaikan pengetahuan peserta dari hasil pre-test dan post-test adalah 19\%. Oleh karena itu, penggunaan software SIPUT merupakan media yang tepat untuk mempermudah penilaian kondisi kesehatan hutan mangrove.
\end{abstract}

Kata kunci: Penilaian kesehatan hutan, software

\begin{abstract}
The importance of information on forest health is needed to find out the disturbances that occur, so it is necessary to monitor forest health regularly. Monitoring forest health is one way to ensure forest sustainability, one of which is mangrove forests. This service aims to increase the understanding of KTH Lestari Indah members regarding the use of the Forest Health Assessment Information System (SIPUT). The target of this service is members of KTH Lestari Indah. It is necessary to know the level of understanding of the participants so that the evaluation is carried out in two stages, namely the initial evaluation (pre-test) and the final evaluation (post-test) by administering a questionnaire. The calculation results showed that there was an increase in participants' understanding of the use of forest health assessment software, with the average pre-test and post-test scores of $61.125 \%$ and $80.125 \%$, respectively. The percentage increase in participants' knowledge from the pre-test and post-test results was 19\%. Therefore, the use of SIPUT software is the right medium to facilitate the assessment of the health condition of mangrove forests.
\end{abstract}

Keywords: Forest health value, software 


\section{Jurnal Pengabdian Kepada Masyarakat BUGUH}

Dipublikasikan

Badan Pelaksana Kuliah Kerja Nyata

Universitas Lampung

Sekretariat Badan Pelaksana Kuliah Kerja Nyata, Universitas Lampung,

J. Prof. Dr. Soemantri Brojonegoro No. 1, Bandar Lampung 35145.

\section{Pendahuluan}

Mangrove adalah ekosistem yang langka di permukaan bumi yaitu hanya memiliki luas sebesar 2\% (Majid, 2016). Desa Margasari berada di Kecamatan Labuhan Maringgai yang salah satunya merupakan desa yang memiliki potensi sumber daya yaitu hutan mangrove. Kualitas kesehatan hutan mangrove dirasakan sebagai dilema penting yang dialami dunia kehutanan saat ini salah satunya yaitu hutan mangrove di Desa Margasari. Aneka macam kegiatan manusia dalam melakukan pengelolaan hutan menyampaikan angguan terhadap hutan. Gangguan-gangguan tersebut berdampak pada kualitas kesehatan hutan yang dikelola oleh manusia khususnya pada hutan mangrove (Safe'i dan Tsani, 2017). Hutan mangrove memberi manfaat yang dapat diperoleh yaitu seperti peningkatan pendapatan, kesejahteraan rakyat dan bahan standar untuk makanan, sedangkan manfaat tak eklusif berupa kelestarian fungsi ekologi yang dimana mirip dengan pengaturan tata air, udara higienis, erosi terkendali, dan lain-lain (Muhammad et al., 2017). Pentingnya manfaat hutan mangrove tersebut memberikan pentingnya keberadaan hutan mangrove yang bisa memaksimalkan manfaat tersebut. Akan tetapi, kondisi hutan yang tidak sehat menyebabkan tidak maksimalnya atau bahkan gagalnya hutan untuk melaksanakan kegunaannya (Safe'i et al., 2019). Krusial dilakukan monitoring perihal kesehatan hutan mangrove dengan cara melakukan evaluasi terhadap hutan mangrove tersebut. Penilaian kesehatan hutan mangrove tersebut diperoleh dengan menerapkan teknik pemantauan kesehatan hutan (Safe'i, 2013).

Pemantauan kesehatan hutan dapat digunakan dalam mengetahui status keadaan hutan yang ada pada saat ini, perubahan yang terjadi dan kecenderungan yang mungkin dapat terjadi pada kondisi hutan (Safe'i, 2018). Mengetahui perihal pentingnya kesehatan hutan dalam menjamin fungsi dan perannya pada waktu sekarang masih dalam kategori kurang, sehingga persoalan tersebut dalam penilaian kesehatan hutan sampai detik ini masih belum mendapat perhatian yang cukup serius (Permadi et al., 2012). Padahal kesehatan hutan salah satu cara untuk menghambat tingkatan dari kerusakan hutan, maka dari itu akan terjamin dari kegunaan dan fungsi hutan itu sendiri, khususnya mangrove yang berada di Desa Margasari Kecamatan (Safe'i, 2015).

Kerusakan-kerusakan yang terjadi dapat ditimbulkan oleh organisme perusak tanaman yang dihasilkan oleh kegiatan pengelolaan yang dilakukan oleh petani itu sendiri. Maka itu, dibutuhkan tindakan untuk dilakukannya pengontrolan pada indikator kerusakan yang terjadi pada tegakan (Kasno, 2019). Pengetahuan perihal kesehatan hutan mangrove untuk mengetahui kemungkinan yang terjadi pada petani yaitu seperti tingkatan agresi, hama perusak tanaman, menurunnya hasil produksi, serta sistem untuk mengendalikan yang wajib dilakukan (Safe'i dan Tsani, 2016).

Penilaian kesehatan hutan masih dilakukan dengan teknik manual yaitu seperti data yang diperoleh dari indikator-indikator kesehatan hutan dituliskan ke tally sheet terlebih dahulu lalu diolah menjadi sebuah file seperti file spreadsheet. Ketika melakukan pengolahan data kesehatan hutan ada beberapa kesalahan yang terjadi dan kesalahan tersebut cukup mendatangkan rugi pada saat pengolahan data dan mengingat pada pemantauan kesehatan hutan dilakukan menggunakan waktu yang tidak begitu cepat (Sumardi, 2007). Kesalahan yang terjadi saat melakukan pengolahan data yaitu seperti data tanaman yang ganda, kekeliruan dalam penggabungan data, serta memasukkan nomor yang sama berulang. Selain itu, kesalahan dapat pula terjadi seperti kesalahan data hilang diakibatkan dari personal komputer yang dipergunakan dalam pengolahan data tersebut hilang (Safe'i, 2017). Cukup banyak kesalahan lain yang bisa terjadi, sehingga perlu dilakukan pengabdian ini kepada masyarakat dengan memiliki tujuan untuk meningkatkan pemahaman anggota Kelompok Tani Hutan (KTH) Lestari Indah mengenai penggunaan Sistem Informasi Penilaian Kesehatan Hutan (SIPUT). 


\section{Jurnal Pengabdian Kepada Masyarakat BUGUH}

Dipublikasikan

Badan Pelaksana Kuliah Kerja Nyata

Universitas Lampung

Sekretariat Badan Pelaksana Kuliah Kerja Nyata, Universitas Lampung,

J. Prof. Dr. Soemantri Brojonegoro No. 1, Bandar Lampung 35145.

\section{Bahan dan Metode}

Pengabdian dilakukan pada bulan Oktober 2021. Sasaran dari kegiatan ini adalah anggota KTH Lestari Indah yang berada di Desa Margasari, Kecamatan Labuhan Maringgai, Kabupaten Lampung Timur. Alat yang digunakan dalam pengambdian ini antara lain meliputi laptop, LCD, kamera, alat tulis, map plastik, pita ukur, meteran, GPS, Kompas, plastik mika, paku payung dan situs pengolahan data Sistem Informasi Penilaian Kesehatan Hutan (SIPUT). Bahan yang digunakan meliputi makalah penyuluhan dan kuesioner. Adapun metode pelaksanaan kegiatan pengabdian berupa : (1) pemberian materi tentang penilaian kesehatan hutan dengan metode ceramah, (2) diskusi terkait materi yang telah disampaikan, dan (3) praktik langsung dengan menggunakan alat Sistem Informasi Penilaian Kesehatan Hutan (SIPUT). Setelah kegiatan pengabdian, dilakukan analisis tingkat pemahaman terhadap peserta dengan menggunakan perbandingan evaluasi awal (pre-test) dan tahapan evaluasi akhir (post-test) serta observasi untuk mengamati kondisi objek sasaran.

Sebelum dan sesudah dilakukan penyampaian materi, tingkat pemahaman para peserta tentang topik yang disampaikan perlu diketahui sebagai evaluasi selama pengabdian berlangsung. Evaluasi dilakukan melalui dua tahapan yaitu tahap pertama (pre-test) evaluasi awal dan tahapan kedua (posttest) evaluasi akhir. Evaluasi pertama atau awal dilakukan dengan cara pemberian kuesioner pada masing-masing peserta. Evaluasi akhir dilakukan sesudah mereka menerima seluruh materi teori. Bentuk evaluasi adalah pengisian kuesioner yang soalnya sama seperti evaluasi awal. Hal ini dimaksudkan untuk mengetahui adanya peningkatan pengetahuan serta pemahaman terhadap materi yang telah disampaikan. Evaluasi menggunakan metode Pre-test dan Post-test berguna dalam menilai sejauh mana pemahaman yang telah dilakukan dengan membandingkan hasil dari kedua evaluasi tersebut, sehingga didapatkan tingkat keberhasilan penyampaian materi apakah berhasil baik atau tidak (Effendy, 2016).

\section{Hasil dan Pembahasan}

Kegiatan pengabdian kepada masyarakat dilakukan hari Minggu tanggal 24 Oktober 2021 di Wisata Hutan Mangrove, Desa Margasari, Kecamatan Labuhan Maringgai, Kabupaten Lampung Timur. Sasaran kegiatan pengabdian dan pelatihan ini adalah kepada anggota KTH Lestari Indah dan masyarakat. Kegiatan ini diikuti oleh para Tim Pengabdian Kepada masyarakat (PKM), Kepala Desa, Ketua KTH Lestari Indah, dan 20 anggota KTH Lestari Indah.

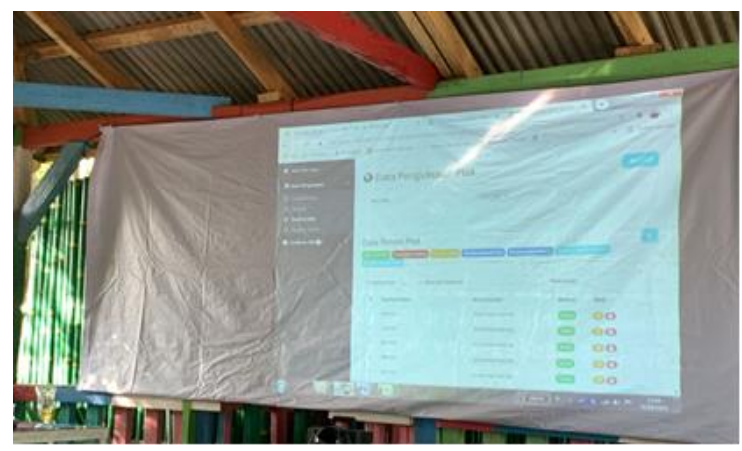

Gambar 1. Pemberian materi tentang penggunaan software penilaian kesehatan hutan

Diatas merupakan pemberian materi tentang penggunaan software penilaian kesehatan hutan kepada peserta pelatihan. Kemudian dilanjutkan dengan pengerjaan pre-test yang dilakukan oleh peserta pelatihan penggunaan software penilaian kesehatan hutan dapat dilihat pada Gambar 2 dibawah ini. 


\section{Jurnal Pengabdian Kepada Masyarakat BUGUH}

Dipublikasikan

Badan Pelaksana Kuliah Kerja Nyata Universitas Lampung

Sekretariat Badan Pelaksana Kuliah Kerja Nyata, Universitas Lampung, J. Prof. Dr. Soemantri Brojonegoro No. 1, Bandar Lampung 35145.

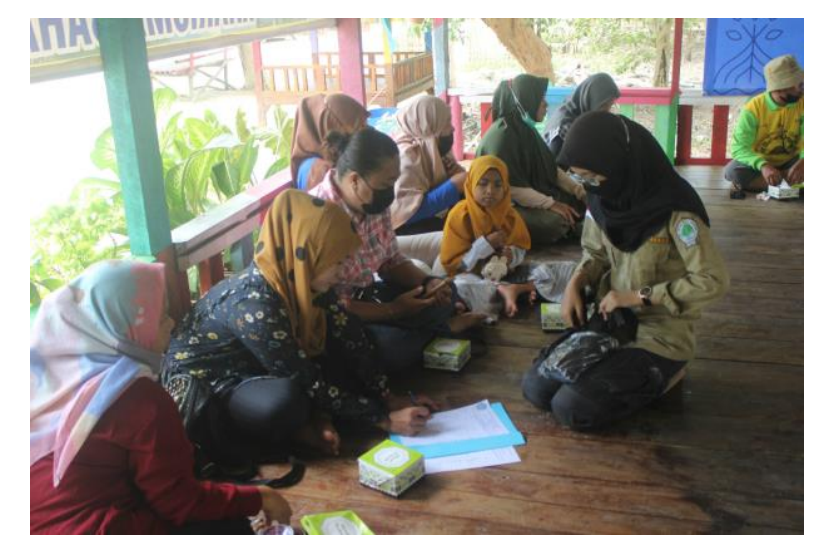

Gambar 2. Pengerjaan pre-test oleh peserta pelatihan

Adapun materi yang disampaikan oleh Tim PKM yaitu tentang penilaian kesehatan hutan. Setelah dilakukan penyampaian materi dilanjutkan dengan sesi diskusi. Sesi diskusi ini berlangsung sekitar 30 menit. Kemudian dilanjutkan dengan evaluasi akhir (post-test). Adanya evaluasi akhir yaitu untuk mengetahui perubahan pemahaman dari peserta pelatihan terkait materi dan praktik penilaian kesehatan hutan digunakan perbandingan persentase rerataan antara nilai hasil evaluasi awal dan evaluasi akhir para peserta kegiatan (Suci dan Jamil, 2019).

Selanjutnya, berdasarkan kegiatan pelatihan penilaian kesehatan yang telah dilakukan, untuk mengetahui apakah kegiatan tersebut terlaksana dengan baik atau tidak selanjutnya dilakukan analisis terhadap pemahaman kepada peserta atau anggota KTH Lestari Indah. Nilai hasil pre-test (evaluasi awal) dan post-test (evaluasi akhir) yang sudah dikerjakan oleh peserta pelatihan digunakan untuk menentukan keberhasilan kegiatan pelatihan. Soal yang dimuat mencakup materi penyuluhan dan praktik yang dilakukan kepada peserta pemantauan kesehatan hutan. Hasil analisis digunakan untuk mengetahui gambaran tingkat perubahan pengetahuan peserta pelatihan sebelum dan setelah mengikuti kegiatan ini. Terdapat 10 pertanyaan pada masing-masing evaluasi. Hasil evaluasi peserta pelatihan penggunaan software penilaian kesehatan hutan dapat dilihat pada Tabel 1 dibawah ini.

Tabel 1. Persentase Rerataan Peserta Pelatihan

\begin{tabular}{|c|c|c|c|}
\hline No. & Pertanyaan & Jumlah Peserta & Persentase Rerata Nilai (\%) \\
\hline 1 & Pre-test & 20 & 61,125 \\
\hline 2 & Post-test & 20 & 80,125 \\
\hline \multicolumn{2}{|c|}{ Persentase Kenaikan } & 19 \\
\hline
\end{tabular}




\section{Jurnal Pengabdian Kepada Masyarakat BUGUH}

Dipublikasikan

Badan Pelaksana Kuliah Kerja Nyata Universitas Lampung

Sekretariat Badan Pelaksana Kuliah Kerja Nyata, Universitas Lampung, J. Prof. Dr. Soemantri Brojonegoro No. 1, Bandar Lampung 35145.

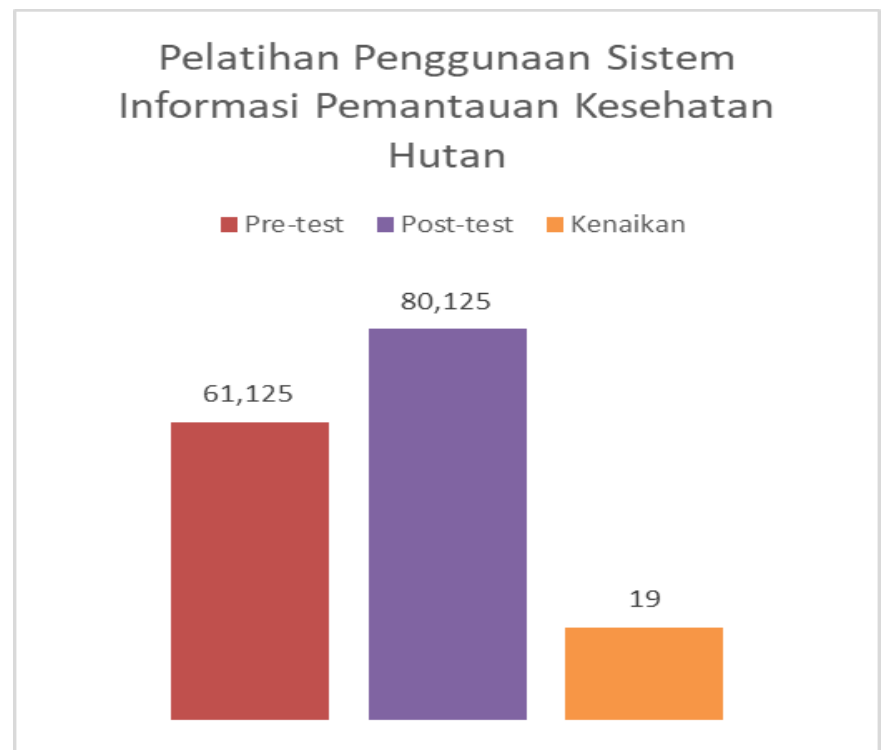

Gambar 3. Perbandingan pencapaian peserta pelatihan penggunaan software penilaian kesehatan hutan

Berdasarkan hasil analisis evaluasi akhir diketahui bahwa terjadi peningkatan pengetahuan masyarakat mengenai penggunaan SIPUT sebagai alat dalam pemantauan kesehatan hutan (Gambar 3). Persentase pre-test sebesar 61,125\%, kemudian terjadi peningkatan sebesar $19 \%$ pada pelaksanaan post-test dengan persentase sebesar $80,125 \%$. Kuesioner yang diberikan tersebut digunakan untuk meningkatkan pemahaman peserta terhadap penggunaan software penilaian kesehatan hutan. Pertanyaan yang diberikan dalam kuesioner yaitu pertanyaan jenis jawaban tertutup. Pertanyaan dengan jawaban tertutup yaitu dimana jawaban alternatif untuk responden sudah tersedia, responden tinggal memilih jawaban yang sudah tertera di lembar kuesioner tersebut yang dianggapnya sesuai (Sandjaja dan Purnamasari, 2017). Kegiatan ini didukung oleh keinginan anggota KTH Lestari Indah untuk memudahkan pengolahan data kesehatan hutan mangrove yang terdapat di Desa Margasari dan dilakukannya pelatihan ini untuk peningkatan pengetahuan anggota KTH Lestari Indah dalam memahami penggunaan SIPUT pemantauan kesehatan hutan.

Pelaksanaan pelatihan penggunaan SIPUT dalam penilaian kesehatan hutan diketahui bahwa sebagian besar masyarakat belum mengetahui cara penggunaannya. Oleh sebab itu, dalam pelaksanaan pemantauan kesehatan hutan diperlukan kegiatan pelatihan penggunaan SIPUT agar data yang diperoleh dari kegiatan pemantauan kesehatan hutan ini dapat langsung ditabulasi. Sehingga masyarakat lebih mudah dan cepat dalam mengetahui bagaimana status kesehatan hutan di lokasi tersebut. Manfaat dari penggunaan software SIPUT yaitu untuk menyimpan dan menganalisis hasil dari pengukuran indikator kesehatan hutan sehingga dapat digunakan untuk melakukan penilaian kesehatan hutan dengan memanfaatkan teknologi informasi. Sistem Informasi Penilaian Kesehatan Hutan atau SIPUT digunakan dalam membantu para pengguna untuk menilai kesehatan hutan, menyimpan data, dan mengolah data yang telah diperoleh sesuai dengan indikator yang telah ditetapkan. Indikator dari kategori kesehatan hutan terdiri dari buruk, sedang, dan bagus (Safe'i, 2017).

Manfaat dari kegiatan pelatihan penilaian kesehatan hutan, diharapkan kepada para peserta dan umumnya pada masayarakat Desa Margasari mampu menerapkan ilmu dan praktik langsung di lapangan terkait pemantauan kesehatan hutan sehinngga dengan mengetahui status dan nilai dari suatu kawasan hutan. Hal ini dapat menjadi contoh dalam mengambil keputusan dan kebijakan yang harus 
Dipublikasikan

Badan Pelaksana Kuliah Kerja Nyata

Universitas Lampung

Sekretariat Badan Pelaksana Kuliah Kerja Nyata, Universitas Lampung

Jl. Prof. Dr. Soemantri Brojonegoro No. 1, Bandar Lampung 35145.

dilakukan dalam pengelolaan dan pelestari hutan khusunya hutan mangrove. Harapan dari kegiatan ini juga, agar para anggota KTH Lestari Indah dapat memberikan ilmunya kepada masyrakat lainnya sehingga dapat terwujudanya kawasan hutan mangrove yang berkelanjutan. Oleh karena itu kegiatan ini diharapkan Harapan dari kegiatan pelatihan ini yaitu agar peningkatan pengetahuan anggota KTH Lestari Indah dalam hal penggunaan software penilaian kesehatan hutan nantinya dapat disalurkan ilmunya ke masyarakat Desa Margasari lainnya. Transfer ilmu penggunaan software penilaian kesehatan hutan kepada masyarakat Desa Margasari lainnya oleh anggota KTH Lestari Indah diharapkan dapat mewujudkan pengolahan data kesehatan hutan dengan (SIPUT) Sistem Informasi Penilaian Kesehatan Hutan yang tersebar atau berada di Desa Margasari. Selain itu, kegiatan pelatihan ini diharapkan dapat meningkatkan kondisi kesehatan hutan mangrove yang berada di Desa Margasari, Kecamatan Labuhan Maringgai, Kabupaten Lampung Timur.

\section{Kesimpulan}

Adanya kegiatan pelatihan penggunaan software penilaian kesehatan hutan ini, pengetahuan anggota KTH Lestari Indah telah meningkat yaitu dengan rata-rata $19 \%$ (61,125\% menjadi $80,125 \%)$. Peningkatan ini menunjukkan bahwa adanya pemahaman yang lebih baik dari para peserta KTH Lestari Indah. Oleh karena itu, pelatihan penggunaan software penilaian kesehatan hutan mampu meningkatkan pengetahuan dan partisipasi masyarakat dalam mewujudkan pengolahan data kesehatan hutan dengan Sistem Informasi Penilaian Kesehatan Hutan (SIPUT). SIPUT merupakan media yang tepat untuk mempermudah penilaian keadaan kesehatan mangrove di Desa Margasari, sehingga lebih efisien dan efektif serta dapat dilakukan pemantauan dan penilaian secara berkala yang lebih mudah.

\section{Ucapan Terima Kasih}

Terima kasih atas pendanaan Pengabdian Kepada Masyarakat (PKM) 2021 Skema Diseminasi Hasil Riset Lembaga Penelitian dan Pengabdian pada Masyarakat (LP2M) Universitas Lampung dengan No. Kontrak 5653 tanggal 6 Oktober 2021 dari BLU Universitas Lampung.

\section{Daftar Pustaka}

Effendy, I. (2016). Pengaruh pemberian pre-test dan post-test terhadap hasil belajar mata diklat HDW.DEV.100.2.A pada siswa SMK Negeri 2 Lubuk Basung. Jurnal Ilmiah Pendidikan Teknik Elektro. 1(2), 81-88.

Kamus Besar Bahasa Indonesia. (2016). Ceramah. Available from: https://kbbi.kemdikbud.go.id/entri/ceramah

Muhammad, F., Izzati, M., dan Mukid, A.M. 2017. Makrobenthos sebagai indikator tingkat kesuburan tambak di pantai utara Jawa Tengah. Jurnal Bioma. 19(1), 38-46.

Pujihastuti, I. (2010). Prinsip penulisan kuesioner penelitian. Jurnal Agribisnis dan Pengembangan Wilayah. 2(1), 43-56.

Safe'i. R, Hardjanto, Supriyanto, dan Sundawati, L.2014. Value of vitality status in monoculture and agroforestry planting systems of the community forests. International Journal of Sciences: Basic and Applied Research (IJSBAR). 18(2), 340-353.

Safe'i, R., dan Tsani, K.M. 2016. Kesehatan Hutan: Penilaian Kesehatan Hutan Menggunakan Teknik Forest Health Monitoring. Plantaxia. Yogyakarta, Indonesia.

Safe'i, R. (2017). Pentingnya Kesehatan Hutan Bagi Pengelola Hutan Rakyat Sengon di Provinsi Lampung Seminar Nasional dan Rapat Tahunan Dekan Badan Kerjasama Perguruan Tinggi Negeri (BKS-PTN) Wilayah Barat, Bidang Pertanian. 962-967.

Safe'i. R, Muludi. K. (2017). SIPUT (Sistem Informasi Penilaian Kesehatan Hutan).

Safe'i, R., Erly, H., Wulandari, C., dan Kaskoyo, H. 2018. Analisis keanekaragaman jenis pohon sebagai salah satu indikator kesehatan hutan konservasi. Jurnal Perennial. 14(2), 32-36. 


\section{BUGUH}

Dipublikasikan

Badan Pelaksana Kuliah Kerja Nyata

Universitas Lampung

Sekretariat Badan Pelaksana Kuliah Kerja Nyata, Universitas Lampung,

J. Prof. Dr. Soemantri Brojonegoro No. 1, Bandar Lampung 35145.

Safe'i, R,. Wulandari, C., dan Kaskoyo, H. (2019). Penilaian kesehatan hutan pada berbagai tipe hutan di Provinsi Lampung. Jurnal Sylva Lestari. 7(1), 95-109.

Safe'i, R., Latumahina, F.S., Suroso, E. dan Warsono. (2020). Identification of durian tree health (Durio zibethinus) in the prospective nusantara garden Wan Abdul Rachman Lampung Indonesia. Journal of Plant Cell Biotechnology and Molecular Biology. 21(41-42):103-110.

Sandjaja, I. E., dan Purnamasari, D. (2017). Perancangan survei kuesioner galangan. Tecnology Science and Engineering Journal. 1(1), 27-33.

Suci, Y. T. dan Jamil, A. S. (2019). Hubungan tingkat kepuasan pelayanan dengan keberhasilan peserta pelatihan teknis bagi penyuluh pertanian. Jurnal Hexagro. 3(2), 47-55.

Sugiyono. (2012). Metode Penelitian Pendidikan. Bandung: Alfabeta. 110.

Yuantari, M.G.C., Widianarko, B., dan Sunoko, H.R. (2013). Tingkat Pengetahuan Petani dalam Menggunakan Pestisida (Studi Kasus di Desa Curut Kecamatan Penawangan Kabupaten Grobogan). Prosiding Seminar Nasional Pengelolaan Sumberdaya Alam dan Lingkungan. 142148. 